УДК 338.24

\title{
ОЦІНКА УПРАВЛІННЯ ПРОЦЕСОМ ФОРМУВАННЯ ПРИБУТКОВОСТІ ПРОДУКЦІї
}

\author{
ASSESSMENT OF THE MANAGEMENT \\ OF PRODUCT PROFITABILITY FORMATION
}

\author{
Поліщук Сергій Володимирович \\ кандидат економічних наук, доцент, \\ Національний технічний університет України \\ «Київський політехнічний інститут імені Ігоря Сікорського» \\ ORCID: https://orcid.org/0000-0003-2609-9347 \\ Буркало Тетяна Михайлівна \\ студентка, \\ Національний технічний університет України \\ «Київський політехнічний інститут імені Ігоря Сікорського» \\ ORCID: https://orcid.org/0000-0003-4656-1770
Polishchuk Sergey, Burkalo Tetiana
National Technical University of Ukraine
"Igor Sikorsky Kyiv Polytechnic Institute"

\begin{abstract}
Стаття присвячена актуальним питанням оцінки управління процесом формування прибутковості продукції підприємства. Проаналізовано та систематизовано основні показники для аналізу прибутковості продукції. Показники, розглянуті в статті, умовно поділено на 4 основних групи, а саме: показники ефективності використання основних виробничих та невиробничих фондів, трудових ресурсів, матеріальних ресурсів та оборотних фондів. Представлено фрормули розрахунку та характеристику кожного показника. Розрахунок та аналіз значень даних показників дають змогу представникам топ-менеджменту суб'єкта господарювання приймати відповідні рішення для покращення фрінансово-господарських результатів та максимально ефективного використання ресурсів.
\end{abstract}

Ключові слова: оцінка, управління, процес формування прибутковості, прибутковість продукції, рентабельність, показники, ефективність.

Статья посвящена актуальным вопросам оценки управления процессом формирования прибыльности продукции предприятия. Проанализированы и систематизированы основные показатели для анализа прибыльности продукции. Показатели, рассмотренные в статье, условно разделены на 4 основных группы, а именно: показатели эфорективности использования основных производственных и непроизводственных фондов, трудовых ресурсов, материальных ресурсов и оборотных фрондов. Представлены фрормулы расчета и характеристика каждого показателя. Расчет и анализ значений данных показателей позволяют представителям топ-менеджмента предприятия принимать соответствующие решения для улучшения фринансовых результатов и максимально эфффективного использования ресурсов.

Ключевые слова: оценка, управление, процесс фрормирования доходности, прибыльность продукции, рентабельность, показатели, эфрфективность.

The article is devoted to topical issues of assessing the management of the process of profitability of the enterprise. One of the main goals of the company is to make a profit and further refinancing in its development. The process of managing the formation of product profitability - as the main source of income - is extremely important for businesses, as its results determine the success of the entity, characterize the main indicators and opportunities for further investment in scientific and technological progress and social development. The management of the process of forming the profitability of products is based on maximizing positive financial indicators from the initial investment in production and sales. A positive result can be achieved through tools such as compiling and implementing a set of tasks to ensure the growth of production and sales, an effective process of managing production costs, improving the efficiency of fixed assets and productivity, as well as improving the management system. 
There are many factors that affect profitability and are subject to risk assessment. These factors are divided into external and internal. External factors influencing profitability are factors that do not depend on the activities of the enterprise. Such factors have a significant effect on the business, but are not influenced by the entity. However, the management of the enterprise must take into account the existence of such factors, determine the degree of impact and the probability of the risk of threat to reduce profits or cessation of economic activity. The main indicators for the analysis of product profitability are analyzed and systematized. The indicators considered in the article are conditionally divided into 4 main groups, namely: indicators of efficiency of use of fixed and non-productive assets, labor resources, material resources and working capital. The calculation formulas and characteristics of each indicator are presented. The calculation and analysis of the values of these indicators allow the top management of the entity to make appropriate decisions to improve financial and economic results and the most efficient use of resources.

Keywords: estimation, management, process of formation of profitability, profitability of production, profitability, indicators, efficiency.

Постановка проблеми. Одна з основних цілей створення підприємства є отримання прибутку та подальше ресрінансування в його розвиток. Процес управління формування прибутковості продукції - як основного джерела доходу підприємства - є вкрай важливим для суб'єктів господарювання, оскільки його результати визначають успішність діяльності суб'єкта, характеризують основні показники та можливості подальших інвестицій у науковотехнічний прогрес та соціальний розвиток.

В основу управління процесом фрормування прибутковості продукції покладено максимізація позитивних фрінансових показників від початкових вкладень у виробництво та реалізацію продукції. Позитивного результату можливо досягти за допомогою таких інструментів як складання та виконання комплексу завдань щодо забезпечення зростання обсягів виробництва та реалізації, есрективного процесу управління витратами на виробництва продукції, підвищення ефективності використання основних засобів та продуктивності праці, а також вдосконалення системи управління суб'єктом господарювання.

Проте, значна частина підприємств стикається з недосконалістю або взагалі відсутністю ефрективної системи управління процесом формування прибутковості продукції. В такому випадку, реалізація продукції не $\epsilon$ прибутковою або недостатньо прибутковою, що не дозволяє такому суб'єкту господарювання розрахуватись 3 кредитами та іншими зобов'язаннями. В кінцевому рахунку це призводить до банкрутства підприємства.

Отже, оцінка управління процесом формування прибутковості продукції є важливим питанням для суб'єктів господарювання, щоб забезпечити високий рівень фрінансових показників, що дасть змогу підвищити конкурентну позицію на ринку та залучати нові інвестиції в розвиток даного суб'єкта господарювання.

Аналіз останніх досліджень і публікацій. Питання, пов'язані 3 фрормування прибутко- вості турбують як і вітчизняних, так і зарубіжних вчених. Дослідження на цю тему висвітлені такими вченими: А. Сміт, Д. Рікардо, К. Маркс, Дж. М. Кейнс, І. Бланк, В. Анфрілатов, М. Білик, В. Савчук, В. Буряковський та інші. Проте, незважаючи на безперервне дослідження проблем, пов'язаних з управлінням процесом фрормування прибутковості, це питання досі $\epsilon$ актуальним для підприємств, особливо в кризових умовах.

Постановка завдання. Мета даної статті полягає у визначенні основних показників оцінки управління процесом фрормування прибутковості продукції підприємства.

Виклад основного матеріалу дослідження. В умовах ринкових відносин підприємство повинно досягати такого розміру прибутковості та інших фрінансових показників, що стабільно утримувати позицію на ринку, а також забезпечувати постійний розвиток виробництва в умовах збільшення конкуренції. Такий результат потребує зусиль від керівництва підприємства у вигляді довгострокового плану щодо управління прибутком та прибутковістю продукції.

Аналіз фрінансових результат підприємства один 3 основних інструментів оцінки ефективності управління процесом прибутковості продукції. Такий аналіз допомагає оцінити не тільки поточні результати, але й спланувати подальші дії стосовно діяльності підприємства.

Український вчений-економіст Бланк Ігор Олександрович виділяє такі елементи механізму управління прибутком: ринковий механізм регулювання, фрормування й використання прибутку та державне нормативно-правове регулювання питань формування й розподілу прибутку підприємства, внутрішній механізм регулювання окремих аспектів орормування, розподілу й використання прибутку підприємства, система конкретних методів і прийомів здійснення управління прибутком [1].

Існує безліч фракторів, які впливають на прибутковість та підлягають оцінці ймовірності ризику. Ці фрактори поділяються на зовнішні та внутрішні. 
Зовнішні фрактори впливу на прибутковість - це фрактори, які не залежать від діяльності підприємства. Такі фрактори мають суттєвий вплив на діяльність підприємства, проте не піддаються впливу зі сторони суб'єкта господарювання. Проте, менеджмент підприємства повинен врахувати існування таких фракторів, визначити ступені впливу та ймовірність ризику загрози для зменшення прибутку чи припиненню здійснення господарської діяльності.

До зовнішніх фракторів можна віднести: природні умови, державне регулювання, демографрічна ситуація на ринку, кон'юнктура ринку, ціни на сировину, конкуренція, інсрляція, податкове навантаження тощо.

Внутрішні фрактори впливу на прибутковість - це фрактори, які залежать безпосередньо від діяльності підприємства. До таких фракторів ми можемо віднести ефективність менеджменту в прийнятті рішень, рівень освіченості та кваліфрікації працівників, цінова та маркетингова діяльність, кількість та якість реалізованої продукції тощо.

Задля ефективного управління формування прибутковості продукції І.О. Бланк виділив п'ять основних принципів:

- інтегрованість із загальною системою управління підприємством;

- комплексний характеру прийняття управлінських рішень;

- високий динамізм управління;

- варіативність підходів до розробки окремих управлінських рішень;
- орієнтованість на стратегічні цілі розвитку підприємства [1].

Процес орормування прибутковості продукції тісно пов'язаний із формуванням процесу здійснення операційної діяльності. Операційна діяльність - це основна діяльність підприємства, яка пов'язана з виробництвом і реалізацією продукції, $є$ головною метою створення підприємства та приносить найбільшу частку доходу.

Для оцінки ефективності управління процесом орормування прибутковості продукції потрібно виділити основні групи показників, а саме:

- ефрективність використання основних виробничих та невиробничих фондів;

- есрективність використання трудових ресурсів;

- есрективність використання матеріальних ресурсів;

- ефрективність використання оборотних фонддів.

Виробничі фонди $€$ частиною основних засобів, які беруть участь у процесі виробництва тривалий час та зберігають при цьому натуральну фрорму. Їхня вартість переноситься на виготовлений продукт частинами, поступово, у міру використання. Відновлення основних виробничих засобів відбувається через капітальні вкладення. Невиробничі основні засоби - це житлові будинки та інші об'єкти соціально-культурного і побутового обслуговування, які не використовуються у господарській діяльності і перебувають на балансі підприємства [2, с. 147]. В таблиці 1

Таблиця 1

\section{Показники ефективності використання основних фондів}

\begin{tabular}{|c|c|c|}
\hline Показник & Формула розрахунку & Характеристика \\
\hline Фондовіддача & $\begin{array}{l}\frac{Q}{\Phi_{c p}} \\
Q-\text { обсяг продукції; } \\
\Phi_{c p}-\text { середньорічна вартість } \\
\text { основних виробничих фондів }\end{array}$ & $\begin{array}{l}\text { Значення показника говорить про } \\
\text { те, скільки продукції вироблено та } \\
\text { скільки надано послуг на кожну гривню } \\
\text { фрінансових ресурсів вкладену в } \\
\text { основні засоби. }\end{array}$ \\
\hline Фондомісткість & $\begin{array}{c}\frac{\Phi_{c p}}{Q} \\
Q-\text { обсяг продукції; } \\
\Phi_{c p}-\text { середньорічна вартість } \\
\text { основних виробничих фондів }\end{array}$ & $\begin{array}{l}\text { Значення показника показує, на } \\
\text { яку суму потрібно придбати основні } \\
\text { виробничі фронди підприємству для } \\
\text { випуску необхідного обсягу продукції. }\end{array}$ \\
\hline $\begin{array}{l}\text { Рентабельність } \\
\text { основних } \\
\text { фондів }\end{array}$ & $\begin{array}{l}\frac{\Pi}{\text { О3 }}{ }^{100 \%} \\
\text { П- річний прибуток підприємства; } \\
\text { О3 - середньорічна вартість } \\
\text { основних засобів. }\end{array}$ & $\begin{array}{l}\text { Показник ефрективності використання } \\
\text { основних фрондів підприємства }\end{array}$ \\
\hline
\end{tabular}

Джерело: складено за даними [4] 
наведено цю групу показників, фрормули розрахунку та коротку характеристику.

Рівень кваліфрікації працівників та продуктивність праці відіграють величезну роль в господарській діяльності підприємства, оскільки від ефрективності прийнятих менеджментом рішень та реалізації даних рішень працівниками залежить ефективність реалізації продукції та отримання прибутку. Для визначення есрективності трудових ресурсів оцінюють показники продуктивності праці та трудомісткість продукції. В таблиці 2 наведено цю групу показників, орормули розрахунку та коротку характеристику.

Показники матеріаломісткості та матеріаловіддачі показують ефективність використання матеріальних ресурсів.

Ефективність використання матеріальних ресурсів залежить передусім від планів та стратегії менеджменту щодо економії таких ресурсів, мінімізації матеріальних витрати та максимізацію реалізації продукції за допомогою матеріальних ресурсів. В таблиці 3 наве- дено цю групу показників, фрормули розрахунку та коротку характеристику.

Для аналізу ефрективності використання оборотних фрондів використовують показники оборотності (ділової активності). Також використовують такі показники як: коефріцієнт закріплення (завантаження) оборотних коштів та показник відносного вивільнення обігових коштів. В таблиці 4 наведено цю групу показників, формули розрахунку та коротку характеристику.

Збільшення вищезазначений показників свідчить про ефрективний процес управління прибутковістю продукції.

Щоб зробити висновок про рівень ефективності фрормування прибутковості продукції, отриманий прибуток необхідно порівняти з понесеними витратами або активами, які забезпечують підприємницьку діяльність, тобто визначити рентабельність [4].

Формули розрахунку та характеристику коефріцієнтів рентабеності представлено в табл. 5.

Показники ефективності використання трудових ресурсів

Таблиця 2

\begin{tabular}{|c|c|c|}
\hline Показник & Формула розрахунку & Характеристика \\
\hline Продуктивність праці & $\begin{array}{l}\frac{T \Pi}{4} \\
\text { TП - обсяг товарної продукції; } \\
\text { 4- чисельність промислово- } \\
\text { виробничого персоналу. }\end{array}$ & $\begin{array}{l}\text { Показник, який характеризує } \\
\text { ефективність використання } \\
\text { персоналу підприємства, показує } \\
\text { здатність працівника випускати } \\
\text { певну кількість продукції за } \\
\text { одиницю часу. }\end{array}$ \\
\hline Трудомісткість продукції & $\begin{array}{c}\frac{T}{Q} \\
Q \text { - обсяг виробленої продукції; } \\
T-\text { затрати робочого часу }\end{array}$ & $\begin{array}{l}\text { Показник, який характеризує } \\
\text { затрати часу на одиницю продукції } \\
\text { (тобто зворотна величина } \\
\text { виробітку): }\end{array}$ \\
\hline
\end{tabular}

Джерело: складено за даними [4]

Таблиця 3

Показники ефективності використання матеріальних ресурсів

\begin{tabular}{|c|c|c|}
\hline Показник & Формула розрахунку & Характеристика \\
\hline $\begin{array}{l}\text { Матеріаломісткість } \\
\text { продукції }\end{array}$ & $\begin{array}{l}\frac{M}{Q} \\
M-\text { величина матеріальних витрат } \\
\text { на загальний випуск товарної } \\
\text { (валової, чистої) продукції; } \\
Q \text { - обсяг виготовленої продукції. } \\
\end{array}$ & $\begin{array}{l}\text { Частка витрат матеріальних } \\
\text { ресурсів (основних і допоміжних } \\
\text { матеріалів, палива, енергії) на } \\
\text { виготовлення одиниці продукції у } \\
\text { загальних витратах. }\end{array}$ \\
\hline Матеріаловіддача & $\begin{array}{l}\frac{Q}{M} \\
M-\text { величина матеріальних витрат } \\
\text { на загальний випуск товарної } \\
\text { (валової, чистої) продукції; } \\
Q-\text { обсяг виготовленої продукції. }\end{array}$ & $\begin{array}{l}\text { Характеризує вихід продукції } \\
\text { з кожної гривні витрачених } \\
\text { матеріальних ресурсів }\end{array}$ \\
\hline
\end{tabular}


Показники ефективності використання оборотних фондів

Таблиця 4

\begin{tabular}{|c|c|c|}
\hline Показник & Формула розрахунку & Характеристика \\
\hline Коефріцієнт оборотності & \begin{tabular}{l}
\multicolumn{1}{c}{$\frac{P}{\text { OK }}$} \\
$P-$ вартість реалізованої \\
продукції; \\
ОК - середній залишок обігових \\
коштів.
\end{tabular} & $\begin{array}{l}\text { Демонструє ефрективність } \\
\text { використання обігових активів } \\
\text { підприємства }\end{array}$ \\
\hline $\begin{array}{l}\text { Швидкість або тривалість } \\
\text { одного обороту обігових } \\
\text { коштів }\end{array}$ & $\begin{array}{c}\frac{T \kappa}{\text { Коб }} \\
\text { TК - кількість днів в періоді; } \\
\text { Коб - коесріцієнт оборотності }\end{array}$ & $\begin{array}{l}\text { Показує швидкість обертання } \\
\text { коштів підприємства за } \\
\text { період, що аналізується. }\end{array}$ \\
\hline $\begin{array}{l}\text { Коефріцієнт закріплення } \\
\text { оборотних коштів }\end{array}$ & $\begin{array}{l}\frac{\text { озср }}{P П} \\
\text { РП-обсяг реалізованої продукції. } \\
\text { ОЗср-середній залишок } \\
\text { оборотних коштів у визначеному } \\
\text { періоді. }\end{array}$ & $\begin{array}{l}\text { Показує частку оборотних } \\
\text { коштів у кожній грошовій } \\
\text { одиниці реалізованої } \\
\text { продукції }\end{array}$ \\
\hline $\begin{array}{l}\text { Показник відносного } \\
\text { вивільнення обігових } \\
\text { коштів }\end{array}$ & $\begin{array}{l}\frac{B p}{Д} *\left(T_{1}-T_{o}\right) \\
\text { ОКвт - сума вивільнених } \\
\text { обігових коштів, грн.; } \\
\text { Вр- обсяг реалізованої продукції } \\
\text { за розрахунковий період; } \\
T_{o} \text { і } T_{1} \text { - тривалість обігу } \\
\text { відповідно в попередньому та } \\
\text { розрахунковому періодах, днів. } \\
\text { Д - дні періоду. }\end{array}$ & $\begin{array}{l}\text { Відображає стабільність } \\
\text { або зростання оборотних } \\
\text { коштів при зростанні обсягів } \\
\text { реалізації продукції. }\end{array}$ \\
\hline
\end{tabular}

Джерело: складено за даними [4]

Таблиця 5

Основні коефіцієнти рентабельності

\begin{tabular}{|c|c|c|}
\hline Показник & Формула розрахунку & Характеристика \\
\hline $\begin{array}{l}\text { Коефріцієнт } \\
\text { рентабельності } \\
\text { активів }\end{array}$ & $\begin{array}{l}\text { Кр.а. }=\frac{\text { чП }}{A} \\
\text { ЧП - чистий прибуток; } \\
A-\text { середня величина активів підприємства }\end{array}$ & $\begin{array}{l}\text { характеризує ефрективність } \\
\text { використання всього } \\
\text { наявного майна } \\
\text { підприємства }\end{array}$ \\
\hline $\begin{array}{l}\text { Коесріцієнт } \\
\text { рентабельності } \\
\text { власного капіталу }\end{array}$ & $\begin{array}{c}\text { Кр.вк }=\frac{4 П}{B K} \\
\text { ЧП - чистий прибуток підприємства; } \\
B K-\text { середня величина власного капіталу }\end{array}$ & $\begin{array}{l}\text { відображає ефективність } \\
\text { використання активів }\end{array}$ \\
\hline $\begin{array}{l}\text { Коефріцієнт } \\
\text { рентабельності } \\
\text { продукції }\end{array}$ & $\begin{array}{l}\text { кр.п }=\frac{\Pi}{C} \\
\text { П- прибуток від реалізації продукції; } \\
\text { C- собівартість реалізованої продукції. }\end{array}$ & $\begin{array}{l}\text { характеризує } \\
\text { ефрективність витрат на її } \\
\text { виробництво і збут }\end{array}$ \\
\hline $\begin{array}{l}\text { Коефріцієнт } \\
\text { рентабельності } \\
\text { продажу }\end{array}$ & $\begin{array}{l}\text { Кр.п }=\frac{\Pi}{B P} \\
\text { П- прибуток від реалізації продукції; } \\
B-\text { виручка від реалізації. }\end{array}$ & $\begin{array}{l}\text { показує, яка питома вага } \\
\text { прибутку в загальній сумі } \\
\text { виручки від реалізації. }\end{array}$ \\
\hline
\end{tabular}

Джерело: складено за даними [4] 
Аналіз показників рентабельності виробництва продукції допомагає визначити, які складові структури виробництва потребують збільшення чи зменшення для більш ефективного використання ресурсів та збільшення прибутковості.

Висновки. Отже, управління процесом формування прибутковості продукції має велике значення в діяльності суб'єкта господарювання, оскільки від ефрективності прийняття управлінських рішень залежить успішність діяльності підприємства і фрінансова стійкість. Головна мета існування комерційного підприємства - отримання прибутку. Основне джерело фрормування прибутку - операційна діяльність та прибутковість реалізованої продукції. Значна частина підприємств характеризується недосконалістю або взагалі відсутністю ефективної системи управління процесом формування прибутковості продукції. В статті наведені показники, які $€$ основними для аналізу прибутковості продукції. Дані показники умовно поділені на 4 основні категорії, які допоможуть управлінцям приймати відповідні рішення стосовно ефрективності господарської діяльності підприємства, підтримувати підприємства на стабільно високому фрінансовому рівні та максимізувати прибуток для подальшого розвитку.

\section{СПИСОК ВИКОРИСТАНИХ ДЖЕРЕЛ:}

1. Бланк И. А. Основы финансового менеджмента. Киев : Ника, 1999. 528 с.

2. Шило В.П., Ільіна С.Б., Доровська С.С., Барабанова В.В. Теоретично-практичний посібник. Київ : ВД «Професіонал», 2016. 288 с.

3. Баканов М.І., Шеремет А.Д. Теорія економічного аналізу : підручник. 4-е вид-во. Москва : Фінанси та статистика, 2011. 416 с.

4. Іванілов О.С. Економіка підприємства [Текст] : підручник. Київ : Центр учбової літератури, 2009. 728 с.

5. Причепа І.В., Руда Л.П. Економіка та організація виробництва. Самостійна та індивідуальна робота студентів : навчальний посібник. Вінниця : ВНТУ, 2017. 186 с.

\section{REFERENCES:}

1. Blank I. (1999) Osnovy finansovogo menedzhmenta [Fundamentals of financial management]. Kyiv: Nika, 528 p. (in Russian)

2. Shylo V., Ilina S., Dorovska S., Barabanova V. (2016) Teoretychno-praktychnyy posibnyk [Theoretical and practical manual]. Kyiv: VD «Profesional», 288 p. (in Ukrainian)

3. Bakanov M., Sheremet A. (2011) Teoriya ekonomichnoho analizu [Theory of economic analysis]: pidruchnyk [a Textbook]. Moscow: Finansy ta statystyka, 416 p. (in Ukrainian)

4. Ivanilov O. (2009) Ekonomika pidpryyemstva [Business Economics]: pidruchnyk [a textbook]. Kyiv: Tsentr uchbovoyi literatury, 728 p. (in Ukrainian)

5. Prychepa I., Ruda L. (2017) Ekonomika ta organizatsiya vyrobnytstva [Economics and organization of production]. Samostiyna ta indyvidual'na robota studentiv: navchal'nyy posibnyk [Independent and individual work of students: a textbook]. Vinnytsia: VNTU, 186 p. (in Ukrainian) 